\title{
Aristotle My Beloved: Poetry, Diagnosis, and the Dreams of Julius Caesar Scaliger
}

\author{
by KRISTINe LOUISE HAUgen
}

Notoriously Aristotelian in his poetic theory, linguistics, and natural philosophy, Julius Caesar Scaliger (1484-1558) also reimagined the lost love poetry that Aristotle himself was said to have written. Scaliger's New Epigrams of 1533 combine a distinctively humanist view of Aristotle as an elegant polymath with a sustained experiment in refashioning the Petrarchan love lyric. Most visibly in poems about dreams and dreaming, Scaliger educes his speaker's erotic despair from philosophical problems in contemporary Aristotelian accounts of the soul, knowledge, and personal identity. The strange but compelling texts that result form a crossroads for Scaliger's own identities as physician, philosopher, and poet.

\section{INTRODUCTION}

$\mathrm{O}$ $\mathrm{f}$ all the intellectual movements said to have been founded in the sixteenth century, Julius Caesar Scaliger's contribution ranks among those for which modern gratitude is, at best, qualified. His Latin Poetics of 1561 rapidly became the standard textbook of Aristotelian, or neoclassical, literary criticism, a discourse that increased in vogue even as the interests of its practitioners narrowed in scope with every generation into the eighteenth century. ${ }^{1}$ Yet if the unrelentingly formalist Poetics represented Scaliger's most durable rapprochement of poetry and Aristotle - it appeared posthumously, after a life spent in Italy and France - Scaliger's earlier literary engagements with the philosopher took place on terrain that remains unfamiliar and provocative. ${ }^{2}$ Scaliger's 1546 volume of erotic lyrics, the Thaumantia, shows that even in the Petrarchan mode that Scaliger, like many fellow Italians, chose to pursue in Latin elegiacs, Aristotle could make his presence felt. Consider a poem entitled "Dreams":

I sleep: now what is good in life can be truly judged, when my sacred dreams show the goddess easy of access.

${ }^{*}$ This essay was written during a Frances Yates Postdoctoral Fellowship at the Warburg Institute, London, where the erudite staff and magnificent library made it an immense pleasure to spend three years. Many friends have been kind enough to discuss Scaliger with me, but I am especially grateful for the saving interventions of Jill Kraye, G. W. Pigman III, and an anonymous reader for Renaissance Quarterly.

${ }^{1}$ Scaliger, 1561; for modern versions, see Scaliger, 1994-; Padelford. On neoclassical criticism, see Weinberg; Bray.

${ }^{2}$ See Billanovich for Scaliger's biography and the great confusion caused by his own fabrications. 
I awaken: now my dreams laugh at me, when they depart, empty, into nothing, on swift foot.

I dream though awake, and I make everything sweet:

I combine fruitless monsters in ways they resist.

I preferred error: we live more in it: error, even though my mistress resists, makes me its own. ${ }^{3}$

The fistful of conventional Petrarchan elements on display here - the illusory dream (1-2), the self-referential account of writing poetry as a dreamlike exercise of imagination (5-6), and the thinly veiled threat of violence (8) — only double our surprise at finding a quotation from Aristotle in the penultimate line, "I preferred error: we live more in it."

In his treatise On the Soul (De anima), Aristotle introduces a discussion of the imagination by quoting the poets Homer and Empedocles on the nature of thinking, an activity which they considered - as Aristotle read them - to be the same activity as sensation. Nonetheless, Aristotle continues, Homer and Empedocles left something out: "They should also have spoken about error at the same time: for error is more natural

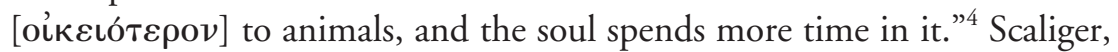
whose familiarity with the treatise On the Soul was intimate, accomplishes at least three things by inserting this passage into the poem "Dreams." $\mathrm{He}$ signals, first, that he endorses Aristotle's use of poetry as a legitimate and serious means for exploring philosophical views. Conversely, Scaliger implies that he regards Aristotle as a careful and philosophically sophisticated reader of verse. Finally, Scaliger sends a polite, but clear, message to Aristotle himself: if the philosopher thought that poets paid insufficient attention to error, he would be well-advised to start reading Petrarch and his followers.

Scaliger's example suggests that Martha Nussbaum is by no means the first Aristotle scholar to believe that the themes of poetry and philosophy can and should be closely involved with one another. ${ }^{5}$ Scaliger's first book of poems, in particular, seems designed to put that proposition to work on a pervasive scale: the New Epigrams (Nova epigrammata), a book of short and primarily erotic verse first published in 1533, then reissued in Scaliger's

${ }^{3}$ Scaliger, 1546, 109-10 (“Thaumantia"): "Somnia. / Dormio: tunc uere censentur commoda uitae: / Cum facilem ostentant somnia sacra Deam. / Euigilo: tunc ridentur mihi somnia, quando / In nihilum celeri uana abiere pede. / Somnio quin uigilans, atque omnia dulcia fingo: / Irritaque inuitis misceo monstra modis. / Plus error placuit: plus illo uiuimus: ille / Vel Domina inuita me facit esse suum."

${ }^{4}$ Aristotle, 1935, 154 (On the Soul 427b).

${ }^{5}$ See Nussbaum, 1990 and 1994. 
collected Poematia of $1546 .{ }^{6}$ The novelty advertised in this volume's title lay neither in its pallid population of sighing lovers nor even in Scaliger's decision to make those lovers speak in Latin elegiacs. By the early sixteenth century, Latin was a standard medium for Petrarchan poets in Italy, so much so that Erasmus could satirize the genre in a Latin colloquy that had the freezing, burning Pamphilus fruitlessly pleading his case to an amused and highly articulate Maria: "My pallor proves how I suffer!" "You're as pale as a ripening cherry or a blushing grape." The New Epigrams constitute an experiment because they conspicuously — sometimes awkwardly import the language and the questions of Aristotelian psychology into a poetic tradition previously dominated by an effulgent Neoplatonism. The mistress in Scaliger's "Dreams" figures, conventionally, as a statue-like goddess to be adored in waking life and communed with by theophany during sleep. In the earlier New Epigrams, by contrast, we meet mistresses who occupy vexed places in the psychology of perception, as tantalizing mental images whose accuracy is literally impossible to check, or as arresting foreign objects that threaten to impose themselves forcibly on a lover's passive mind. In literary terms, if the isolated quotation from Aristotle in "Dreams" works as an inset Aristotelian commentary on a Petrarchan poem, the New Epigrams work more broadly as imitations of the Petrarchan tradition at large, tending to detach the lover's constitutive anxiety from a metaphysically conceived mistress and spread it amply over the sensible world. ${ }^{8}$ No one inclined to judge literary value would place the resulting poems among the greatest of the sixteenth century. Nonetheless, a close look at the New Epigrams and their contexts shows us what must count as a tantalizing road not taken for Scaliger and sixteenth-century poetry. Had Scaliger persevered in his project or found emulators, the meaning of Aristotelianism to literary scholars today would surely have been radically different.

${ }^{6}$ See Scaliger, 1546, 42-84. The citations that follow are from Scaliger, 1533. The volume's title was apparently chosen by Scaliger: see his prefatory letter, sigg. aii ${ }^{\mathrm{r}-\mathrm{v}}$ : "I have imitated no one in the world except for myself, because it pleases me to be the author of New Epigrams" ("Nullum omnium hominum imitatus, praeter me ipsum, propter quod NOVORUM EPIGRAMMATUM me autorem non poeniteat").

${ }^{7}$ Erasmus, vol. 1, pt. 3, p. 277 ("Proci et puellae"): "PAMPHILUS. Atqui pallor arguit exanguem ... MARIA. ... Sic palles ut cerasium maturescens aut uva purpurascens.” On Latin elegiacs, see Catanzaro and Santucci; Bottiglioni, especially 9-71; Forster; Ludwig, 1976; Bradner; see also Hutton.

${ }^{8}$ On imitation as the imitation of a genre, see Genette, 73-85. 


\section{SCAliger's Dreams: Aristotle the Love Poet?}

Scaliger's project in the New Epigrams proceeded from motives more specific than a simple refusal to conform. His lifelong distaste for straightforward argument, however, means that to piece these motives together, we need to examine a number of texts that Scaliger wrote and read. In his preface to the New Epigrams, Scaliger writes only of his aim to have "finished off every topic with novel, ingenious, and unexpected inventions." Years later, however, he planted a broad hint about the precise nature of that ingenuity in the preface to his 1540 treatise On the Causes of the Latin Language. Here Scaliger reveals that, although a philosopher, he now feels emboldened to write on linguistics because just such a union of disciplines already flourished in classical antiquity: not only Galen and Plato, but Aristotle himself, Scaliger explains, combined their more serious work, in good sixteenth-century fashion, with the pursuit of humanistic studies. "Didn't Aristotle think humanistic studies were so relevant to himself that he often actually emended words, other times explained them, or inquired into them, or even invented them? He wrote on poetics; he wrote on rhetoric. To say nothing of love poetry and the like, he wrote an entire treatise teaching us in how many modes a thing can signify [On Interpretation]. In fact, according to him, not only is Grammar a part of Philosophy - something no sane person denies — but we ought to infer that philosophy cannot be separated from the knowledge of grammar."10

This redoubtably interdisciplinary Aristotle, who must have sounded to Scaliger's humanist contemporaries like a particularly prolific version of themselves, seems to have arisen from a fifteenth-century genealogy that we will trace shortly. At the moment, a more specific, not to say baffling, question demands attention. Why anyone might contemplate speaking of "love poetry and the like" in relation to Aristotle becomes clear only when we look into the sixteenth-century's standard source for Aristotle's biography, the Lives and Characters of the Ancient Philosophers by Diogenes Laertius (fl. third century CE). According to Diogenes, Aristotle not only

${ }^{9}$ Scaliger, 1533, sig. aiir: "sed praeter caetera id studui, ut materiae omnes, nouis inuentionibus atque argutissimis, minusque expectatis concluderentur."

${ }^{10}$ Scaliger, 1540, sigg. bb ${ }^{\mathrm{r}-\mathrm{v}}$ : "Nonne Aristoteles adeo ad sese pertinere arbitratus est [sc. humanioris sapientiae studia], ut saepenumero ipsa emendet vocabula, alia explicet, quaedam uel inuestiget, vel etiam pariat? Scripsit ille de Poetica: de Rhetorica scripsit. Amatoria vero, atque alia eiusmodi ut omittam, perpetuo commentario id egit, ut sciremus, quot modis quippiam significare possit. Cuius profecto iudicio Grammaticam non solum esse Philosophiae partem, id quod nemo sanus negat: sed ne ab eius quidem cognitione dissolui posse intelligeremus." Cf. a similar passage in Scaliger, 1561, sig. aiir . 
commented on poetry but wrote poetry himself, including a paean, hexameter poems, and elegiacs. Diogenes' article offers a sample of the latter, "Daughter of a lovely mother," the opening of an erotic poem that would have sounded to sixteenth-century readers like the arresting Greek original of Horace's Ode 1.16 "O matre pulchra filia pulchrior." ${ }^{\prime 11}$ In the widely published fifteenth-century life of Aristotle by Guarino da Verona (13701460), we find ready endorsement of Diogenes' account of Aristotle as a poet. Although Guarino freely rejects other parts of Diogenes' biography as the malicious fabrications of Aristotle's detractors, he mentions "poems" in a catalogue of Aristotle's writings on language and literature that bears a marked family resemblance to Scaliger's. ${ }^{12}$

Scaliger seems never to have asserted straightforwardly that Aristotle composed erotic poems, but a parallel case shows that he neither distrusted Diogenes on principle nor considered love poetry unworthy of the dignity of ancient philosophers. Diogenes also quoted eight complete epigrams attributed to Plato, addressed to men and women, which can all be read as erotic. ${ }^{13}$ Although Marsilio Ficino (1433-99) bitterly denied that Plato had written these, basing his case for Plato's moral probity on an epigram supposedly written in his praise by none other than Aristotle, Scaliger believed that Plato was in fact their author - and that Plato therefore deserved to be expelled from his own ideal, poet-free republic. ${ }^{14}$ This was not an unnatural conclusion when the Planudean Anthology, which Scaliger had studied before 1533, contained two dozen poems attributed to Plato, including three of the elegies that Diogenes had quoted. ${ }^{15}$ As Scaliger

${ }^{11}$ Diogenes Laertius, 1490, sig. sviiv ("Aristoteles"): "Elegiae quarum est initium: formosae matris filia"; in the first Greek edition, Diogenes Laertius, 1533, 227 :

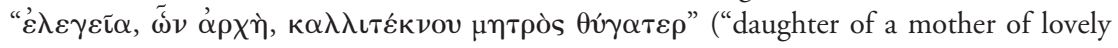
children"). See also Rose, 598-600.

${ }^{12}$ Guarino da Verona, sigg. $\beta \nmid 3^{\mathrm{v}}, \beta \nmid 2^{\mathrm{r}}$.

${ }^{13}$ Diogenes Laertius, 1490 , sigg. dviii ${ }^{\text {r-v }}$ ("Plato"); and 1533, 144-46. Ludwig, 1963, argues brilliantly that several of the epigrams are Hellenistic and not by Plato, though he is less persuasive in denying that the epigram to Dion of Syracuse might also be erotic.

${ }^{14}$ Ficino, 1491b, sig. a $4^{\mathrm{r}}$; Scaliger, 1574, 13 (“De poetis a Platone eiectis e repub.").

${ }^{15}$ The elegies quoted by Diogenes appear in Florilegium, sigg. $136^{\mathrm{v}}$ (to Aster), $189^{\mathrm{r}-\mathrm{v}}$ (to Dion), and $191^{\mathrm{r}}$ (to Alexis). See also Ficino, 1491b, sigg. a $4^{\mathrm{r}-\mathrm{v}}$ : "Aristippus of Cyrene forged lascivious poems about loose women and boys, which he attributed to [Socrates, Xenophon, and Plato]. He meant, by falsely citing the example of the great philosophers, to win a greater license for himself to misbehave" ("Aristippus ... cyrenensis ... finxitque horum nomine [sc. Socrates, Xenophon and Plato] carmina quaedam in scorta puerosque lasciua / videlicet ut falso magnorum philosophorum exemplo liberiorem ipse peccandi licentiam nancisceretur"). For Scaliger's knowledge of the Greek Anthology, see Nichols, 42; Hutton, 193. 
composed the Poetics, meanwhile, he demonstrated complete awareness of Diogenes' claims for Aristotle as a poet. We see this when Scaliger defends one of Diogenes's stories that Guarino da Verona rejected, to the effect that Aristotle was placed on trial for writing a paean - a genre usually reserved for gods and demigods - addressed to a living contemporary. Scaliger printed Aristotle's poem in full, invented a genre of paean that involved only praise rather than divine worship, and instantly ascribed Aristotle's offending poem to it: a simple reading of the text, Scaliger remarked, not only exculpated the philosopher of the Athenians' charges but also showed that he was equal to Pindar as a poet. ${ }^{16}$ Finally, in his critical discussion of Horace's ode "O matre pulchra filia pulchrior," the poem that appeared to translate the Greek elegy quoted by Diogenes as Aristotle's, Scaliger says nothing overtly about Aristotle as a poet, yet he finds a circuitous philosophical pretext for calling attention to Diogenes' biography nonetheless: "Prometheus was not 'forced,' nor was his action 'forced' ... Aristotle and other philosophers in Diogenes Laertius held that the human being is the measuring stick of nature." ${ }^{17}$ Scaliger, a prolific Aristotelian philosopher himself, would never ordinarily cite the vague and anecdotal Diogenes in preference to Aristotle's own texts - nor, it happened, did Diogenes' life of Aristotle mention the doctrine of the measuring stick at all. Scaliger's tortuous method of commentary, piling obliquity on obliquity, confirmed for well-informed readers that he shared their knowledge of Aristotle's putative erotic elegy; yet it also allowed Scaliger to avoid a historical argument about Aristotle as a poet that must have depended, like Ficino's argument against Plato as a poet, on unprovable claims about decorum and the philosopher's personal dispositions.

Given Scaliger's lifelong inclination to write in Aristotle's historical lacunae - he knew that Aristotle's own treatise on poetics had been transmitted in a damaged state, while his own treatise On the Causes of the Latin Language applied Aristotelian methodology to a subject that Aristotle had plainly never studied — it seems likely that the New Epigrams were an

${ }^{16}$ Scaliger, 1561, 48 (book 1. chapter 44); cf. Diogenes Laertius, 1490, sigg. sv ${ }^{\mathrm{v}}-$ svi $^{\mathrm{r}}$; and 1533, 217; cf. also Athenaeus, The Deipnosophists, 7:230-34 (696a-697b), who denies that the poem is a paean at all. Scaliger added line divisions to the 1533 Greek text from Diogenes and changed several readings. See Guarino, sig. $\beta \dagger 2^{r}$ for the latter's rejection of the story of the trial.

${ }^{17}$ Scaliger, 1561, 340 (6.7): "neque Prometheus coactus fuit, aut coactus fecit . . \& Aristoteles \& alii apud Laertium philosophi, hominem rerum naturalium regulam dixere" (quoting Horace, Ode 1.16.14, "coactus"). Cf. Diogenes Laertius, 1490, sig. m5v ("Protagoras"): "omnium rerum modus \& mensura homo est earum quidem quae sunt ut sunt.” For the Greek, see Diogenes Laertius, 1533, 472. 
exercise in exploring what Aristotle would or could have written as an erotic elegist, even if Scaliger could never bring himself to say that Aristotle had definitely done so. ${ }^{18}$ We know that Scaliger was not the first of his contemporaries to reconstruct a lost work by Aristotle in a surprising genre. In 1531, the philosopher Agostino Nifo (ca. 1473-1538), whom Scaliger would later claim had been his teacher, showed how a quintessentially Neoplatonic genre could be aggressively reframed as Aristotelian, publishing twin treatises De pulchro liber (On Beauty) and De amore (On Love) whose respective points of departure were Aristotle's Nicomachean Ethics and On the Soul. ${ }^{19}$ Nifo, too, evidently knew Diogenes Laertius, who had attributed to Aristotle one book each On Beauty (De pulchro in Ambrogio Traversari's fifteenth-century translation) and On Love (Amatorius)..$^{20}$ But Nifo, like Scaliger, avoided referring to Diogenes, so that only his more erudite readers would have perceived the historical basis for what must otherwise have seemed an elaborate philosophical joke.

If both Scaliger and Nifo were abetted by Diogenes' claims about Aristotle's lost writings, however, their imaginings about those writings also answered to broader contemporary habits of speaking about Aristotle, some of which we saw in Scaliger's ideal portrait of the philosopher in On the Causes of the Latin Language. In the first place, since Guarino's time, it had become conventional for Aristotle's apologists to describe his writings not only as virtually universal in scope, but also, more specifically, as a union of what the fifteenth century often saw as the conflicting forces of humanism and scholasticism. Thus Ermolao Barbaro (1454-93?), addressing students with whom he proposed to read the entire extant works of Aristotle, emphasized that no one needed to attend a "philosophical school" to comprehend this author, and, as a further inducement, that Aristotle had written on dialectic, rhetoric, and poetics. ${ }^{21}$ Angelo Poliziano overtly denied that his own study of Aristotle made him a philosopher; conversely, Poliziano could praise Homer's poetry by pointing out that

${ }^{18}$ On Aristotle's Poetics, see Scaliger, 1561, sig. aiiir: "Aristotelis Commentarij mutili sunt, nequid liberius excidat nobis"; see Jensen for a discussion of De causis linguae latinae.

${ }^{19}$ See Nifo, 1531 and 2003; Kraye, 382-85; Mahoney, 100-01. For Scaliger's claim that he was a student of Nifo, see Scaliger, 1557, sig. *ii" ("Candido Lectori”); for a discussion of this, see Billanovich, 237.

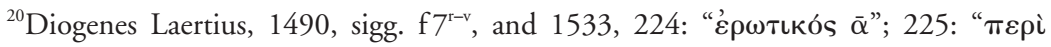
к $\alpha \lambda$ ог̃ $\bar{\alpha}$; Rose, $105-07$.

${ }^{21}$ On the humanist appeal of Aristotle, and the lack of any need for a "schola philosophica," see Barbaro, 1498, sigg. $s 8^{\mathrm{r}}-\mathrm{t} 1^{\mathrm{r}}$. For the dating of the oration to 1485 or earlier, see Barbaro, 1943, 1:91-93 (Barbaro to Arnoldo di Bost, Venice, 1 June 1485), especially 92. 
Homer, along with Empedocles, was often quoted in Aristotle's philosophical writings. ${ }^{22}$ Thus Barbaro and Poliziano, both writing in the 1480 s, assumed not only that humanists and scholastics held comparable stakes in reading the philosopher, but, further, that Aristotle's own excellence consisted less in an abstract and generalized omniscience than in his actual expertise in reading and writing many genres. This vision found a parallel in the way Poliziano proceeded to treat Homer, another ancient intellectual for whom claims of universal knowledge had been current since late antiquity. ${ }^{23}$ As Scaliger and Nifo would later do for Aristotle, Poliziano discovered that Homer had worked in many more forms than was generally realized, detecting tragedies, comedies, love poetry, and plaintive "epigrams" (epigrammata) embedded in the Iliad. ${ }^{24}$ Scaliger admired both Poliziano and Homer in the 1530s, but whether or not he read the essay on Homer from which Poliziano's remarks come, a larger observation about Scaliger's Aristotelianism is close at hand. ${ }^{25}$ In the New Epigrams, as in many of his other writings, Scaliger performed his allegiance to Aristotle in a double register: as a scholastic eager to apply Aristotle's methods and doctrines in all fields of knowledge, and, simultaneously, as a humanist who emulated, or imaginatively supplemented, the writings of a venerated historical actor.

\section{Scaliger's Philosophy: True Dreams and INFALLIBLE MADMEN}

If Scaliger the literary historian believed that Aristotle had written love poetry, only Scaliger the philosopher could say what the themes and problems of that poetry might be: tracing the affinities of the New Epigrams, then, must involve a look at Scaliger's other Aristotelian writings. In some measure, nearly any volume of Scaliger's natural philosophy might serve this purpose. ${ }^{26}$ For example, we encounter a distinctly Petrarchan moment in Scaliger's commentary on Aristotle's Historia de animalibus when

${ }^{22}$ Poliziano, sig. \&10 (“Oratio in expositione Homeri”); see Maïer, 93, for the dating of this text to 1486-87. On Poliziano disclaiming the title philosopher, see Celenza, 523-26.

${ }^{23}$ See Lamberton and Keaney.

${ }^{24}$ Poliziano, sigg. \& $88^{\mathrm{v}}-\& 9^{\mathrm{r}}$ ("Oratio in expositione Homeri”); his discussion closely follows that of pseudo-Plutarch: see Homer, sigg. Evi ${ }^{\mathrm{r}-\mathrm{v}}$ (De vita et scriptis Homeri, chapters 213-15). On Poliziano and Homer, see Grafton, 1992, 154-55, and 159-61.

${ }^{25}$ On Scaliger's admiration for Homer during this period, see Nichols, 30, 32-34; for Scaliger's later view in the Poetics, see Grafton, 1992, 161-62. Scaliger's 1535 iambic poem Nemesis imitated Poliziano's Manto. However, cf. Scaliger, 1561, 309 (6.4).

${ }^{26}$ On Scaliger's commentaries in natural philosophy, see Lüthy and Perfetti. 
Scaliger, expanding on Aristotle's claim that animals as well as humans possess memory and thought, remarks that "this indeed we have in common with brutes. A bull repeats in his memory the image of an absent cow." ${ }^{27}$ Our most promising source, however, is Scaliger's commentary on the ancient Hippocratic text about medical diagnosis from dreams; Scaliger published this commentary in 1539 but said that he had composed it some time earlier. ${ }^{28}$ Not only is the commentary on Hippocrates concerned at length with Aristotelian psychology, its subject - the dream - is also one of the most recurrent themes of the New Epigrams, to a degree that is exceptional even for a sixteenth-century volume of Petrarchan poetry. We might think of the dream as the royal road, if not to Scaliger's unconscious, then to the textual kinship between the New Epigrams and Scaliger's more conventionally Aristotelian writings, and, further, to the social kinship between Scaliger the philosopher and Scaliger the poet.

For the purpose of understanding his experiments as a Petrarchan poet, two of Scaliger's arguments in the commentary on Hippocrates are especially arresting. First, Scaliger insists that, contrary to received opinion, the intellect participates centrally in producing dreams. The purpose of this idea, as we will see, was to guarantee that the medical dream could both convey correct information and be decoded in a reasoned, systematic way. Secondly, in the course of broader discussions about the soul at large, Scaliger emphasizes two doctrines derived (unlike his previous claim) from Aristotle's On the Soul: that the intellect could never err, and, more generally, that the soul was incapable of madness. In combination, these claims lent the medical dream a redoubtable diagnostic authority. Manifestly, they also spat in the face of any number of conventional ideas about dreaming, with implications Scaliger would take up at length only in his New Epigrams. But we see already why Scaliger's poem "Dreams," with its easy glossing of the erotic dream as simple "error" and, indeed, its speaker's plangent wish to remain in error, fell totally outside the philosophical concerns of the commentary on Hippocrates. ${ }^{29}$ In the philosophical regime of the New Epigrams, on the other hand, Scaliger's earliest dream poems had been far less dismissive and substantially more troubling.

The commentary on Hippocrates' On Dreams arose in the first instance from Scaliger's own teaching and, perhaps, his practice as a physician. $\mathrm{He}$

${ }^{27}$ Aristotle, 1619, 30 (Scaliger's note at 1.2.24): "Hoc [sc. cogitare] etiam brutis commune est. Speciem vaccae absentis taurus in memoria repetit."

${ }^{28}$ Hippocrates, 1539; on the composition of this text, see Scaliger's preface, sigg. $\beta 3^{\mathrm{v}}-\beta 4^{\mathrm{r}}$.

${ }^{29}$ For the text of "Dreams," see above, pp. 819-20. 
doubtless believed, like most of his professional contemporaries, that dreams, skillfully interpreted, could signal an incipient illness or disorder before any symptoms appeared in the patient's body. However, to comment on Hippocrates in 1539, only thirteen years after the first complete Latin translation and twelve years after the first edition in Greek, was more than a diligent reporting of ancient doctrine. To publish on Hippocrates also signaled one's position in something of a professional vanguard - the cohort of erudite doctors who translated and commented on the ancient Greek texts that now competed for attention with standard textbooks like Avicenna's Canon. ${ }^{30}$ The notion that dreams played a role in diagnosis was not rescued from oblivion by the medical humanists: Avicenna, for example, had discussed a number of dreams that signaled the state of the temperament. ${ }^{31}$ The appeal of Hippocrates' text, equally medical and aesthetic, lay in its Greekness, in its monographic rather than encyclopedic form, naturally in the new dreams it explained, and, one suspects, in the paucity of its theoretical assumptions. Largely avoiding explanations, the treatise took the form of a simple list of quasi-aphorisms, cataloguing medically significant dreams (about daily life, about celestial bodies, about rivers and trees) along with the treatment each one called for, such as vomiting, purging, exercise, rest, or diet. Although the text did occasionally refer to correspondences between the human body and the elements of the world, this system was not obviously identical with sixteenth-century humor theory, nor was any straightforward explanation presented for its causal mechanism. ${ }^{32}$ Here, then, was a treatise both crying out for commentary - it lacked any by Galen — and easy to comment upon because it was extraordinarily short (seven pages in a modern edition). ${ }^{33}$

Scaliger announces his Aristotelian priorities early in the commentary when he remarks, disapprovingly, that "Hippocrates has omitted a definition of the dream." Scaliger also perceives a remedy close at hand: "let us take one from philosophy," he proposes, by which it soon becomes evident

${ }^{30}$ See Wear, French, and Lonie; Nutton; Siraisi, 1997, especially 119-45; Siraisi, 1987. The first published complete works were Hippocrates, 1525 and, in Greek, Hippocrates, 1526.

${ }^{31}$ Avicenna, $273-77$ (1.492, 1.494, 1.498-500).

${ }^{32}$ On this "micro-macrocosmic" system, see Jouanna, 161. The authorship of the entire corpus of writings ascribed to Hippocrates is considered questionable today, and the text on dreams is certainly not authentic: see Smith. In the sixteenth century it was printed and discussed as an independent treatise, although the text is treated today as book 4 of the treatise On Regimen.

${ }^{33}$ The commentary on Hippocrates is discussed by Roselli; Garanderie. 
he means Aristotle's On the Soul, with parts of the Parva naturalia. ${ }^{34}$ Yet to turn to Aristotle for any clear account of the predictive dream was, in fact, to enter a world of uncertainty and vexation, as generations of commentators had already complained. Albertus Magnus (ca. 1193/1206?-80), the thirteenth-century bishop and professor, was among the most eloquent of these: "What Aristotle wrote concerning divination from dreams is short, incomplete, and full of unanswered questions. ... It lacks proofs; the discussion is plain, appearing to draw little on natural philosophy, and it neither describes the kinds of dreams nor shows what a given dream means.... The cause of such dreams is left uncertain." ${ }^{35}$ Although Albertus's indictment was launched in particular against Aristotle's short text $O n$ Divination from Dreams, no straightforward help was forthcoming, as Scaliger discovered, even if one appealed for clarification to the other Aristotelian writings that were obviously relevant: On Dreams, On Sleep and Waking, and the much broader treatise On the Soul. ${ }^{36}$ Thus Agostino Nifo, who undertook precisely that approach in his 1523 commentary on the Parva naturalia, decided also to compose a treatise of his own on the art of interpreting dreams, which he included in his commentary. Nifo described this contribution as a fourth book to follow the three books of Aristotle's own treatise On Dreams, because, as Nifo put it bluntly, "Aristotle said little or nothing about the art of dream interpretation." ${ }^{37}$ Scaliger, on the other hand, systematically avoided imputing any inadequacy to Aristotle, preferring to represent his own arguments as the true - though misunderstood - opinions of the master. It followed that if Scaliger was determined to pursue an Aristotelian method in his explanation of Hippocrates - to supply, as Albertus had suggested, a definition, an account of the medical dream's causes, and an account of its signification -

\footnotetext{
${ }^{34}$ Hippocrates, 1539, 2: "Ac quanquam omisit Hippocrates definitionem. . . nos autem e philosophia accipiamus."

${ }^{35}$ Albertus Magnus, sig. $35^{\mathrm{r}}$ ("De somno et vigilia," 3.1): "hoc ipsum quidem quod de diuinatione dicit Aristoteles breue quidem est et imperfectum et habens plurimas dubitationes... quare carens probatione: sed simplex et parum physice habens videtur esse narratio: nec species somniorum neque probationem somnij aliquid significandi in se continens. ... in incerto relinquitur causa talium somniorum."

${ }^{36}$ Aristotle, 1935, 374-84 (On Divination from Dreams), 348-70 (On Dreams), 31844 (On Sleep and Waking).

${ }^{37}$ Nifo, 1523, sig. $114^{\mathrm{v}}$ : "But because Aristotle said little or nothing about the art of dream interpretation, I have added a fourth book, in which I will speak about the interpretation of dreams. I will say what others believe and what ought to be stated on the basis of Aristotle" ("Sed quoniam Aristoteles pauca aut nulla asseruit de artificiosa somniorum interpretatione, nos librum $4 \mathrm{~m}$ adiecimus, in quo de somniorum interpretatione dicturi / ea dicemus quae alij sentiunt, et quae secundum Aristotelem dicenda sunt").
} 
he must simultaneously perform bold exegetical maneuvers on Aristotle himself.

Scaliger bit into this task with evident relish, in more instances than we can examine here. But his first major argument, that the intellect took part in the dream, was a case in point. Scaliger was not the first Aristotelian philosopher who included the intellect in dreaming: Albertus Magnus and Averroes (1126-98), among others, had earlier suggested the same, although those writers were concerned with guaranteeing the possibility of true prophetic dreams, rather than with medicine. ${ }^{38}$ On the other hand, Scaliger certainly was saying something novel with respect to Aristotle. In the treatise On Dreams, Aristotle states plainly that the dream is not produced by the intellect, but rather by the imaginative part of the soul. ${ }^{39}$ And he specifies with equal clarity that when the intellect does work during sleep, that activity, by definition, does not count as a dream. ${ }^{40}$ Scaliger ignores this problem on a majestic scale when he announces, without preliminaries, that for Aristotle dreams were "the representation not only of things we understand, but also of things we sense." ${ }^{41}$ With this maneuver, Scaliger lays the groundwork for a far more robust endorsement of the predictive dream than Aristotle himself ever provided.

Indeed, it is hard to avoid the conclusion that in choosing to comment on a book about medical dreams, Scaliger also deliberately chose a battle with Aristotle. A brief look at Aristotle's laconic statements reveals the problems Scaliger had to solve if he were to show why the medical diagnosis of dreams was both accurate and routinely possible. In Aristotle's $\mathrm{On}$ Divination from Dreams, which addresses predictive dreams directly, we find an account of the medical dream that was perfunctory, not to say cool. Like the prophetic dream in general, the medical dream is just possible, Aristotle allows, but to the most restricted degree and by the most prosaic means. The small beginnings (archai) of an imminent disease might well be perceived during sleep, he writes, because sleep tends to magnify all sensations or motions: accordingly, sleepers "think it is thundering and lightening when there are small echoes in their ears, and that they are tasting honey and sweet flavors when a drop of phlegm is trickling down

\footnotetext{
${ }^{38}$ Albertus Magnus, sig. $35^{v}$ ("De somno et vigilia" 3.3), and sig. $38^{\mathrm{r}}$ (3.10); Averroes, 98-101.

${ }^{39}$ Aristotle, 1935, 352-53 (On Dreams 459a).

${ }^{40}$ Ibid., 348-51 (On Dreams 458b). For an excellent discussion of this issue, see van der Eijk, 2003, especially 28, 33-34.

${ }^{41}$ Hippocrates, 1539, 2: "Aristoteles somnium non solum eorum quae intelligerentur, dixit esse repraesentationem, sed etiam quae sensu perciperentur” (emphasis added).
} 
their throats." ${ }^{\prime 2}$ These bathetic examples, which constitute the bulk of Aristotle's discussion of the medical dream, would hardly be helpful to a physician who would like to explain why, for example, a dream about a river could reveal the medical condition of the patient's blood. ${ }^{43}$ Aristotle envisages no semiotic connection between dream and symptom any more complex than sheer physical amplification, nor does he explain what the beginnings of disease might feel like, much less how they might seem when amplified as he describes. Perhaps worst of all for Scaliger's ambition to legitimate the medical dream, the magnified sensations Aristotle describes do not count as dreams at all, properly speaking: having defined the dream elsewhere as purely an activity of the imagination, Aristotle here carefully describes his sleepers' misperceptions only as events happening "during sleep." $^{44}$

Scaliger's solution to these manifold difficulties impresses by its elegance as well as its audacity. By forcibly inserting the intellect into dreams, he nullifies Aristotle's reluctance or even hostility about the predictive dream. Scaliger proceeds easily to explain where the information in a medical dream comes from, how that information is turned into visual representations, and how the resulting dream can be reliably interpreted. He proposes, in the first place, that the medical dream rests on information about the body that the soul "understands" or "knows" (cognoscit) whether in the form of colors, shapes, or quantities - with the result that the soul, through dreams, can "explain the condition of the body at quite an early point." ${ }^{\prime 45}$ Secondly, the images actually seen in a medical dream are produced by "varying the modes" (variare modos) of the knowledge to be represented: a technical term from Aristotelian logic, the process of "varying modes" would in turn guide the responsible physician in his method of interpreting dreams. So, according to Hippocrates, for example, a dream that involves conducting one's daily business as usual signifies good health. Scaliger adds the explanation that for someone who attends daily Mass, it is therefore good to dream not only of Christian worship but also of ancient pagan worship, because the difference between these involves only the

${ }^{42}$ Aristotle, 1935, 376-77 (On Divination from Dreams 463a).

${ }^{43}$ Hippocrates, 1539, 47, 73.

${ }^{44}$ Aristotle, 1935, 368-69 (On Dreams 462a), cf. 350-51 (458b); see also 376-77 (On Divination from Dreams 463a). On the exclusion of these perceptions from the category of dreaming, see van der Eijk, 1995.

${ }^{45}$ Hippocrates, 1539, 2: "Cognoscit [sc. anima] quae intus sunt, in corpore scilicet. Ibi cum quibusdam quasi coloribus, figurisque, ac quantitatibus pingitur earum rerum, quas intus nacta est. Quare his affectionibus satis opportune statum corporis explicat.” 
"mode" of worship: "the quality or quantity of the same substance." 46 And Scaliger proceeds to use overtly logical language as he explains many other dreams that Hippocrates reports. For example, taking up Hippocrates' statement that "changes in the appearance of a river represent motions of the blood," he couches his comments in the place-logic terms of from and to: "Changes in rivers, he says, is various. From their motion, we arrive at the motion of the blood, and from the nature of that motion, likewise: excess, from their overflowing; insufficiency, from their receding; and finally, from their turbulence, imbalance." ${ }^{27}$ In sum, the medical dream is possible for Scaliger because it rests on knowledge produced, conveyed, and decoded intellectually. Beyond systematizing and theorizing the ancient text in this way, Scaliger also discovered that Hippocrates had been a partner in his own unorthodox claim about the intellect: the ancient physician described so many dreams about the stars that he was clearly, Scaliger thought, assuming that the patient deployed some intellectual knowledge of astronomy even while dreaming. ${ }^{48}$

Through his argument about the intellect, then, Scaliger effectively demands that dreams be taken seriously. The implications are wide, and Scaliger begins to consider some of them even here in the commentary on Hippocrates. His bracing new account of the dream precipitously increased the dream's authority, not only against Aristotle's noncommittal discussion of the predictive dream, but also against the dream's far broader and better-known association with the imagination and its powers of deception. Here was precisely the point where Scaliger the poet saw his opportunity to reconceive the dream poem on unfamiliar and disturbing foundations: what follows if dreams, in general, are neither accidental nor trivial - if they cannot be readily dismissed as unreasonable and wrong? In the commentary on Hippocrates, however, Scaliger limits himself to answering the converse question: is the intellect now implicated in the endless distortions

${ }^{46}$ Ibid., 23: "Dixit, eodem modo repraesentari [quoting Hippocrates]: ut naturae constantiam significet. Nam modus, est qualitas quantitasue eiusdem substantiae. Potest enim quispiam diurno exerceri sacrificio. Hoc idem si somniet, variare modum potest: ut pro vero Deo nostro, si recipiat obsoletum cultum veterum monstrorum. Ea $<\mathrm{e}>\mathrm{dem}$ actionis erit species, modus autem alius."

${ }^{47}$ Ibid., 73: "Fluminum mutata facies sanguinis motum repraesentat"; "Fluminum mutationem ponit variam: ab eorum motu, motum sanguinis: a motus ratione, tantundem: excessum, ex redundantia: defectum, e subsidentibus: postremo a turbulentia, imparitatem.”

${ }^{48}$ Ibid., 3: "In this work Hippocrates does say things that pertain to the intellect, for example, when he holds that the soul understands the courses of the stars, and other similar things" ("Tum hic Hippocrates ea proponit, quae ad intellectum pertineant: veluti cum vult $\mathrm{ab}$ anima iniri rationem cursuum stellarum, atque alia talia”). 
and errors that are conventionally ascribed to the dream? For example, in Scaliger's poem "Dreams," should we say that the speaker's intellect deserves blame for the error that attracts him and eludes him?

On the contrary. Scaliger apparently responds to just these difficulties with his second set of surprising arguments: he proceeds to claim that the intellect, insofar as it always acts irreproachably upon the information it is given, is totally incapable of error. Further, the soul as a whole is incapable of madness. Unlike Scaliger's insistence that the intellect participated in dreaming, these doctrines are drawn straightforwardly — or, at any rate, plausibly - from Aristotle. ${ }^{49}$ However, in combination with the new role of the intellect in dreaming, they force paradoxical conclusions, which Scaliger takes some pleasure in emphasizing. Among other consequences, Scaliger suggests that no matter how mistaken a dream might be in conventional terms, the intellect that produced it must inevitably be correct, and no matter how mad a person might appear to be, his soul, including his intellect, remain eminently sane.

The provocation Scaliger launches here against any ordinary account of dreaming is direct and apparent, because in these parts of the commentary on Hippocrates, his attention shifts from the medical dream per se to human psychic states at large. Mental illness - discussed by Hippocrates as the meaning of several medical dreams - provides Scaliger's opening. Although Hippocrates' text takes mental disease for granted, as a state produced by perturbations acting on the soul, Scaliger rejects out of hand the very possibility of such an effect. If diseases or substances could touch and move the soul, or make it sick, that would indicate a material soul which indeed, Scaliger points out, Hippocrates implied when he wrote that the soul was made of fire and air. ${ }^{50}$ But to preserve the soul's immateriality, as Scaliger meant to do, one should assert that the soul cannot be moved and, a fortiori, that it cannot be changed by the body or anything else: disease can only afflict the spirits, which transmit images for the mind to receive. ${ }^{51}$ On the other hand, it was obvious that madness did exist. But Scaliger, following Aristotle, describes madness as a state of the entire person and, emphatically, not of the soul. It follows that, in the case of a

${ }^{49}$ For excluding the soul from disease, see Aristotle, 1935, 48-49 (On the Soul 408b), and 188-89, 174-75 (433a, 430b) for excluding intellection, judgment, and sensation from the possibility of error.

${ }^{50}$ Hippocrates, 1539, 12-13; cf. Aristotle, 1935, 46-49 (On the Soul 408a-08b).

${ }^{51}$ Hippocrates, 1539, 47: "Ego vero cum meliori seculo nego in anima quicquam esse morborum, sed in spiritibus, ut in rebus species deferentibus." For the immobility of the intellect, see Aristotle, 1935, 48-49, 192-93 (On the Soul 408b, 434a). 
mad person, we should not say that the soul is mad, but rather that the soul is the instrument through which the person is mad. ${ }^{52}$ The soul, for its part, always operates correctly - a doctrine that, in turn, leads Scaliger onward from psychology to a resonantly strange epistemology.

If madness is not a condition of the soul, Scaliger explains, then the errors committed by mad people should likewise not be ascribed to the soul. Even in the most thorough madness or delusion, Scaliger claims, "the soul never errs. It takes up what it is given, but [during madness] it is given defective representations" by the material spirits in the blood. ${ }^{53}$ So instead of erring, the soul of a mad person (or an infant) receives wrong mental pictures and thus, as Scaliger provocatively puts it, "knows wrongly." ${ }^{54} \mathrm{We}$ will shortly see how Scaliger put this conviction into effect in his New Epigrams - describing an unhinged Petrarchan lover, who, systematically and miserably mistaken about his beloved, is at the same time inevitably correct. For now, we should notice that Scaliger's argument about the unerring soul and "wrong knowledge" cannot be regarded as merely an opportunistic flourish in the commentary on Hippocrates. Indeed, there is every reason to think he took the claim seriously, even in distant contexts with very different argumentative demands. In his Exotericae exercitationes in natural philosophy against Girolamo Cardano (1501-76), published eighteen years after the commentary on Hippocrates, Scaliger returns with relish to his argument about the impossibility of error, now adding a corollary about the definition of truth: just as the soul, given a wrong image, can nonetheless "know wrongly" and make no error, so too an utterance should be counted as true if it corresponds to the mind of the speaker, even if the utterance fails to match the real state of the world. Imagine, Scaliger explains, an engraved ring bearing a likeness of Girolamo Cardano - a bad likeness that actually resembles Cardano very little. The image on the ring is false, yet pressing the ring into wax makes an

${ }^{52}$ Hippocrates, 1539, 15; cf. 95; Aristotle, 1935, 46-47 (On the Soul, 408b).

${ }^{53}$ Hippocrates, 1539, 15: "Homo sapit per animam: furit autem per animam: quoniam per prauas species fit repraesentatio. Itaque anima non fallitur. excipit enim quod offertur. sed offeruntur vitiosa." See also 17.

${ }^{54}$ Ibid., 16: "praue cognoscit." The entire passage reads: "If the soul could be defective in itself, an infant would be evil. Instead, the soul knows wrongly, due to the defectiveness of the instruments and the images" ("Si enim anima ab seipsa praua esset, statim infans esset malus. Sed contra ipsa instrumentorum, ac specierum prauitate, praue cognoscit"). The possibility of "knowing wrongly" was apparently suggested by Aristotle, 1935, 160-61 (On the Soul 428a), although that possibility is explicitly denied on 156-57 (427b). 
impression that is true. ${ }^{55}$ In the essayistic, polemical setting of the Exercitationes, Scaliger could easily avoid explaining the consequences of such a remarkable doctrine by simply declaring victory and abandoning the field. But the New Epigrams, to which we should now turn, represent the rare case in which Scaliger allowed himself to write at length about the questions he found so fascinating and so awkward.

Setting together the New Epigrams and the commentary on Hippocrates will show us that, in Scaliger's practice, the boundary between philosophy and poetry was both permeable and real. Scaliger could cross this border via the dream because the two discourses, as he found them, shared many thematic preoccupations - perception, memory, the passions, knowledge, and error among them. On a structural level, moreover, both Aristotelian psychology and Petrarchan lyric specialized in describing inner experience of a highly stylized kind: that of a stationary subject who directs his attention to a single person or thing - Socrates, a horse, a beloved, a tomb - exercising every faculty in turn with every possible result. At the same time, Petrarchan poetry inevitably provided a strenuous test of both Scaliger's general Aristotelianism and his more idiosyncratic principles. How was a philosopher who denied the possibility of error to write in a tradition in which, as Scaliger suggests in his poem "Dreams," errors about the beloved usually lay at the center of the speaker's anxiety and experience? Again, what kinds of poems could result if Scaliger treated the Petrarchan dream of the beloved as an intellectual event, rather than as a divine revelation or as a mistake committed by imagination and desire? How, finally, would Scaliger figure the workings of intellection and imagination in a discursive setting that obliged him actually to narrate the soul's activity, rather than simply asserting it as a fait accompli?

\section{Scaliger's Poetry: The Intellect Is in Anguish}

Just as the commentary on Hippocrates forced a confrontation with Aristotle, so love poetry, for Scaliger, required energetic interventions with respect to Petrarch. Neither the commentary on Hippocrates nor any of Scaliger's other writings in natural philosophy had yet been published when the New Epigrams appeared in 1533. Scaliger labored to make it clear, however, that he was engaged in an original and provocative project. In his

\footnotetext{
${ }^{55}$ Scaliger, 1557, sigg. $3^{\mathrm{v}}-4^{\mathrm{r}}$. Aristotle, 1935, 136-37 (On the Soul 424a) used the example of a ring impressing wax to explain the process of sensation.
} 
preface, he praises the novelty of his own "inventions," perhaps suggesting through the Latin word's multiple senses that his bold innovations are to be found in the ways in which, through the rhetorical process of invention, he elaborates and expands upon traditional themes. ${ }^{56}$ Scaliger also gave his poems florid titles, sometimes nearly as long as the verses they introduce: in an extreme case, the first poem in the volume is called "To the Shades of Those Who, Despairing in Love, Have Voluntarily Brought Death on Themselves, to Whose Number He Vows to Add Himself, If, Indeed, Anyone Can Die Who, Wasted Away by Love, Is Already a Shadow of Himself and Not a Living Man." ${ }^{57}$ Although not all of Scaliger's ninety-six poems are amatory - a few are epigrams of praise addressed to male friends and contemporaries - the majority of the collection unfolds in the tone of impossibly overwrought erotic despair announced in "To the Shades." Even a casual reading gives the impression of hyperbolic excess, a superabundance whose literary valences seem to include, on the one hand, absolute and unrelenting engagement with Petrarchan conventions and, on the other hand, the distinct possibility of parody. That Scaliger set several of his poems in Padua - a city where Petrarch spent time near the end of his life, but also the contemporary Italian center for Aristotelian philosophy, where Scaliger himself perhaps studied — only heightens this effect of energetic, even perverse doubling. ${ }^{58}$

Two quite different poems from the New Epigrams show us how Scaliger refashioned the erotic lyric in the terms of his own personal Aristotle. Above all in poems about dreaming, Scaliger rejected a Neoplatonic approach that would have portrayed the beloved as divine, ideal, or, as we will see, stationary and impassive. Yet he also refused to safeguard the lover's personal identity by reserving a reassuring space for normalcy outside the dream, as he did in his later poem "Dreams": here, Scaliger involves the entire soul in the Petrarchan narratives of desire, dream, and doubt that were more conventionally understood as the uncertainties of the imagination alone. ${ }^{59}$

The first of these poems asks for direct comparison with Scaliger's "Dreams," as it transposes the Petrarchan poetics of the antithetical image into a rapid and unresolvable exchange of antithetical propositions. A fatal

${ }^{56}$ Scaliger, 1533, sig. aiir: "inventiones."

${ }^{57}$ Ibid., sig. aiiir: "Ad umbras eorum, qui desperatis amoribus sponte sibi mortem consciuerunt, quorum numerum sese aucturum pollicetur, si tamen quispiam mori possit, qui amore tabidus iam umbra sui est, non uiuus homo."

${ }^{58}$ The poems set in Padua are pointed out in Billanovich, 236.

${ }^{59}$ For the text of "Dreams," see above, pp. 819-20. 
attraction to the aporetic is already announced in its anxious title, "He Is in Anguish from Intractable Imagining: He Is Where His Beloved Is, or Nowhere":

Am I with you? Or did I depart from here without you, Circia? Am I here with you? Or did I burst the hard bonds and flee?

If I am not, what is this form rushing to meet my eyes?

If I am, why do our arms deny you to me?

I am present and search for myself here - O fate! — but I am absent and search for myself elsewhere: why am I with myself without myself?

This image is not empty for you, my eyes, because either I am there and here together, or I shall never be any I at all. ${ }^{60}$

These anxious questions and answers evidently comment on a scene like the conventional Petrarchan one we saw in Scaliger's "Dreams" — a dream or vision of the beloved that both demands and repels the speaker's belief. Yet the difference from "Dreams" is profound, and not only in this poem's thematics of irresolution and the speaker's palpable fear that his desire might annihilate him rather than his beloved. In "He Is in Anguish," undecidability is suggested not through narrative but through a disputation, in which propositions and their instantaneous negations work, as in a public debate or a sixteenth-century philosophical treatise, to emphasize disagreement and contradiction. Philosophy enters more specifically in Scaliger's language of "form" (imago) and "image" (species), words that belong to a syndrome of technical terms from psychology that fill the New Epigrams: repraesentatio (representation), effigies (replica, simulacrum), idola (same), and nota (mark). Instead of freezing and burning, despairing and exalting, this lover suffers via a poetics of the proposition that eventually ruptures its own most fundamental premise, namely, the law of non-contradiction that underwrites the entire enterprise of dialectic. The speaker concludes, instead, that "either I am there and here together, or I shall never be any I at all" - either $A$ and not- $A$, or $B$ and not- $B$. If we read this speaker's trajectory through the doctrines of Scaliger's commentary on Hippocrates, it becomes clear that, even if the soul always judges correctly what it is given, in real terms this correctness can only deepen the pain of what Scaliger refuses to call error: in the dream-epistemology of this poem,

\footnotetext{
${ }^{60}$ Scaliger, 1533, sig. $17^{\mathrm{r}}$ : “Ex pertinaci imaginatione angitur, sese esse ubi amica sit, aut nusquam. / Sum tecum? an ne abs te hinc abij mea Circia? sum ne / Hic tecum? an rupi uincula dura fugax? / Si non sum, quaenam haec oculis occursat imago? / Si sum, quid mihi te brachia nostra negant? / Praesentem praesens me quaero, ô fata, sed absens / Absentem, mecum me sine, cur ego sum? / Non uana haec uobis species mea lumina, quando / Aut ibi, \& hic sum una: aut nuspiam ego ullus ero."
} 
"all of the above" simply is the true and unsatisfying answer to the speaker's urgent questions.

That we have here precisely a representation of "knowing wrongly" the condition of mad people with sane souls, according to Scaliger's commentary on Hippocrates - was in fact the interpretation suggested years later by Scaliger himself in some of the many passages of the Poetics that advertised the excellence of his own poetry. The poem's rigorously logical form, in the first place, answered to both Scaliger's multiple intellectual identities and the proprieties of its own genre - at least if we take seriously a remark that Scaliger let slip as he politely savaged the Quattrocento Latin poet Marco Marullo. "In writing an epigram," Scaliger writes, the true poet "should consider himself a philosopher: a good epigram shares the virtues of an epicheirema," that is, of a syllogism whose premises are given explicit proof. ${ }^{61}$ More specifically, during a discussion of the epigram proper, Scaliger refers first in complimentary tones to his own New Epigrams, then gives his reader a series of instructions for portraying erotic madness. Epigrams, he writes, should "close sometimes wittily, sometimes abruptly and as though something is missing. For a lover's greatest wisdom is madness. This can be depicted through broken sentences or by repetitions. Much desire should be expressed, and many thoughts." ${ }^{2}$ If repetitions and "many thoughts" signify madness, "He Is in Anguish" surely suffers from a serious case, most acutely if something is missing at its end. Compared with Scaliger's "Dreams," this poem lacks a closing moment of distancing, or anamorphosis, in which the speaker's error is recognized — what Scaliger's Neoplatonist contemporaries might have glossed as reason's entry as a charioteer to harness the passions. However, for Scaliger the philosopher, as we have seen, madness is not the absence of reason or intellect, but wrong knowledge obtained through impeccable reasoning. Nor, this epigram emphatically suggests, is madness a divine frenzy that reveals higher truths to prophets and poets. ${ }^{63}$ The "greatest wisdom" of Scaliger's lover, if we continue to read retrospectively from his Poetics, consists instead in

${ }^{61}$ Scaliger, 1561, 297 (6.4): "Verus poeta dicat, se in Epigrammate oportere esse philosophum: accedit enim bonum Epigramma ad virtutes Epicherematis"; for the epicheirema, see 134 (3.71).

${ }^{62}$ Ibid., 170 (3.126): "[I]n Amatoriis eo usque exercitati sumus, ut nouorum Epigrammatum inscriptione gloriari fortasse licuerit. Haec esse decet candida, culta, tersa, mollia, affectuum plena. Interdum arguta in fine, interdum deficientia \& mutila. Maxima enim amantis sapientia, amentia est. quam depictam dabis in defectibus sententiarum, aut in repetitionibus. Multa desiderii, multa cogitationum expressio." For the amentia (madness) of lovers and beloveds, see also 52 (1.50).

${ }^{63}$ On poetic madness, see Megna; Buck, 87-97. 
asking whether a person energetically involved in wrong knowledge can remain a self, logically and otherwise. Scaliger's lover articulates this doubt not only in the aporetic conclusion of his debate, but also in his earlier question, "why am I with myself without myself?" - which could be translated equally well as "with myself without myself, why am I an I?" In effect, Scaliger shows here what hundreds of other Petrarchan poets ought to have written had they understood the actual nature of the soul and the most telling ways of staging erotic madness in verse - even as Scaliger the philosopher acknowledges that saving the integrity of the intellect through the construction of "wrong knowledge" only shifts the problem of explaining madness to the more pervasive plane of personal identity in general.

In another poem in the New Epigrams, "The World Is at Rest, $\mathrm{He}$ Alone Is Afoot, and He Is Torn by Various Passions," Scaliger moves from elucidating the mode of the lover's knowledge to probing the modes of his action or inaction, another canonical theme of Petrarchan anxiety. Abandoning the antithesis as a structural principle, Scaliger here follows a different convention in narrating a solitary journey through a landscape on the model of Petrarch's Solo e pensoso. ${ }^{64}$ But "The World Is at Rest" again recalls a dream, in the first place through the speaker's uncertain corporeality and position, as he seems to be involved in flying, sudden translocation, and the reenactment of memory. That he is "afoot" (excitari) suggests that he may be either awake from sleep or risen from the dead.

Now the dewy path refreshes the nocturnal woods: now there is silence, and deep night is in the middle of its course.

Now fat dreams soften the savage beasts: and the wild wave is quiet, its swellings laid low.

Even the stars moving in heaven are commanded to go on silent horses, lest they take away sleep.

When hollow echo is wrongly thrown out in half-ruined caverns, it helps, when struck, by its uncertain murmur.

I alone am carried, unendingly, trackless, into a different air: and a slow path takes my daring feet.

Telesilla led me here in triumph long ago: in the law that she laid down, love is a prideful ruler.

Had she not nursed her gentle lover on tears, my entrails wounded by cupids of uncertainty,

to what slow applause would my fiery torch have raged, from what heavy bonds would my neck have been free.

${ }^{64}$ Petrarca, 80 (Solo e pensoso). For other humanist imitations of the poem, see McLaughlin, 170; Keller. 
Now I desire desiring not to, I pursue myself, and I flee myself pursuing: and eagerly I return, myself the bloody prize. $^{65}$

To begin with an ending, the penultimate line here - "now I desire desiring not to, I pursue myself, and I flee myself pursuing" - clearly reminds us of the logic of antithesis that drives Scaliger's "He Is in Anguish." "66 Yet the line belongs emphatically to this poem in that it both evokes the dream and invokes the classical distinction between doing and suffering, or acting and being acted upon. Scaliger's words apparently allude to the pivotal scene in the Iliad when Achilles pursues Hector around the walls of Troy, a frustrating contest seemingly without end: "As in a dream, the one pursuing cannot catch the one fleeing: the one cannot escape the other, nor can the other catch him. ${ }^{67}$ The next, and final, line of Scaliger's poem finishes Homer's story, making the speaker into both the victorious Achilles and Hector's bloody corpse. But if the impossibility not to mention the egomania - of this scene appears familiar, its function is not: set in a present "now" (nunc), these lines form an ending in a strong sense, drawing back, as "He Is in Anguish" does not, from the narrative of the rest of the poem. In that memory or dream, we encounter a new Achilles: a beloved endowed with the power to act robustly, indeed violently, upon a piteously complaining speaker. This beloved allows Scaliger to substitute for the customary monologue of lament a remembered narrative of desire and affliction, in which erotic doing and suffering are not mutually exclusive.

A memory or dream seems to begin in the poem's second set of four lines, as Scaliger's catalogue of the night, which initially portrays a world

\footnotetext{
${ }^{65}$ Scaliger, 1533, sig. 21": "In omnium rerum quiete, sese unum excitari, uariisque affectibus distrahi. / Roscida nunc reficit nocturnos orbita saltus: / Nunc tacet et medias nox agit alta uias. / Effera nunc pingues mulcent animalia somni: / Et torua instratis fluctibus unda silet. / Quinetiam tacitis labentia sidera caelo, / Ne somnos adimant ire iubentur equis. / Vix bene semirutis echo proiecta sub antris / Concaua, nec certo murmure pulsa fauet. / Vnus in abductas longum feror auius auras: / Et legit audaces semita lenta pedes. / Huc me sub ueteri cogit Telesilla triumpho: / Cuius in arbitrii lege superbit amor. / Quae blandum lacrymis nisi me lactasset amantem, / Sauciaque incertis corda cupidinibus: / Ah ah quam lento fureret fax ignea plausu: / Quamque forent grauibus libera colla modis. / Nunc nolens uolo, meque sequor, fugioque sequentem: / Atque ultro redeo praeda cruenta mihi." In line 1 the printed text reads "Rosida" (for Roscida), in line 3 "mulceat" (for mulcent), in line 11 "Telessilla" (for Telesilla). The second and third of these were corrected in Scaliger, 1546, 72.

${ }^{66}$ For the text of "He Is in Anguish," see above, p. 837.

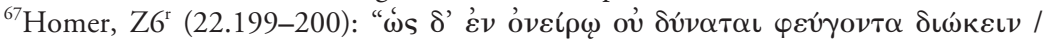

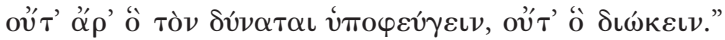


unproblematically and desirably at rest, proceeds to two scenes in which the inorganic world is first animated and then constrained. The silence of the stars results from their obedience to a command, not from the inevitable nature of the world: meanwhile, the echo, struck "wrongly" (vix bene) and contrary to the imperative to silence, is sentient enough to "help" ( favet) by restraining its voice. The world's quietness is also, then, the sound of a confinement or wakeful frustration. The poem's speaker makes his appearance in lines 9-10, yet notwithstanding his "daring" (audaces), he spectacularly fails to impose himself on this increasingly unquiet scene. Traveling in the passive voice — "I am carried" ( feror) — he is subjected to three semantic reversals that tend to impose the landscape, grammatically and otherwise, on him. The Latin avius ("trackless") always refers to places, like forests or deserts, rather than to travelers, so that Scaliger's trackless speaker assumes the character of the terrain around him. Again, as in English, one's feet in Latin can "take" (legit) a path, but it is a jarring change for a path actively to "take" a wanderer's feet as it does here, and still a further reversal for the path, rather than the feet, to be "slow" (lenta) ${ }^{68}$ Apparently alive like the stars and the echo, this speaker is also in a state of obedience, willing or otherwise, although we still cannot see who, or what, is issuing the commands.

As the speaker is delivered into the place of memory proper in line 11 ("here," huc), a far more energetic human actor irrupts onto the scene: a beloved who nourishes, but also coerces ("led," cogit), rules, wounds, and binds. As the beloved is animated out of the condition of an unreachable star or the echo of a spoken name, we exit the primal scene common to Aristotelian psychology and Petrarchan fantasy - one observer sighing or inveighing at one stationary object - and enter a bracing domain of ethics. Poetically this is a pastoral moment, albeit a frustrated one: instead of an outdoor assignation at midday, this speaker is the subject of a public humiliation at midnight - led by the neck in an empress' victorious procession (sub ueteri ... triumpho). We think, at this point, no longer of Petrarch's Rime, but of his Trionfi d'Amore and, particularly, of the moment when Petrarch's speaker turns from a mere spectator at the parade of love's historical victims into an outraged prisoner himself. ${ }^{69}$

If Scaliger's beloved assumes the martial place of Achilles in this scene of remembered experience, the benighted Hector nonetheless remains quite alive: when struck, he speaks, and indeed we learn in line 15 that he writes

\footnotetext{
${ }^{68}$ In the case of avius, Scaliger demonstrably knew the customary usage: see the phrase loca avia in Scaliger, 1533, sig. 24' ("Philomelam consolatur").

${ }^{69}$ Petrarca, 534-36 ("Triumphus Cupidinis” 3.85-150).
} 
poetry to no small applause. Telesilla is the painful, but indispensable, cause of this writing, and in naming her for an ancient Greek lyric poet Scaliger proposes her as the speaker's learned, if malevolent, collaborator. By contrast, in the poem's present time of solitary remembering, the speaker is obliged to strike and vanquish himself - to act as both Achilles and Hector - if he is to remember, or write. Erotic verse, it appears, is a bloody prize obtained through self-abuse.

In the scene of memory, the speaker's desire escapes both the stark antithesis of acting or suffering proposed in the poem's closing lines, and those lines' familiar reversion to a doubled self that desires while desiring not to (nolens uolo). In the violent memory of line 14, the "cupids of uncertainty" (incertis cupidinibus) are both corporeal assailants from without and the speaker's own desires (cupidines). Desire itself is doubled, overdetermined, and - given the ineluctable presence of the beloved anything but a synonym for lack. Scaliger's speaker instead feels desire as an echo, a reply to the beloved's superabundance that is spoken in his own fiery voice. That this desire, in line 14 , is also uncertain - an epistemological word, suggesting that the speaker's intellect participates in his erotic doing and suffering - encourages us to ask what philosophical concerns may have impelled Scaliger to his wholesale revision of the standard Petrarchan erotic scene.

Scaliger showed no discernible interest in the philosophical study of ethics, much less in contemporary questions about the relative excellence of the sexes. It seems most likely that the actions and passions of this poem's speaker are in fact a translation, or echo, of the doing and suffering of the intellect in Aristotelian psychology. As Scaliger's Aristotelian contemporaries often point out, and as Scaliger himself assumes in his commentary on Hippocrates, "the intellect never thinks without an image": that is, without receiving a phantasma given to it by the spirits that are the soul's instruments. In the terms of Scaliger's poem, the intellect only speaks when it is struck. ${ }^{70}$ On the other hand, Scaliger believed the intellect was not obliged simply to repeat unchanged the images that it received. Given a plenum, the soul could come to know what a vacuum would be; given a truth, the soul could know what fiction is. ${ }^{71}$ His poem's speaker, on this theory, could easily have written conventional Petrarchan poems bewailing Telesilla's absence or indifference at the very moment he suffered her real and present attentions.

Still more fundamentally, however, this poem's complicated verdict on

\footnotetext{
${ }^{70}$ Hippocrates, 1539, 9-10; Aristotle, 1935, 176-77 (On the Soul, 431a).

${ }^{71}$ Hippocrates, 1539, 10.
} 
questions of agency replies directly to the popular Platonic model of knowledge and desire that informs most Petrarchan erotic poems, including Scaliger's own subsequent "Dreams." The "half-ruined caverns" from which Scaliger's speaker is "alone ... carried ... into a different air" may be none other than the cave in Plato's Republic, into which shadows and echoes brought imperfect knowledge of a higher world to prisoners in chains. ${ }^{72}$ By contrast, the "slow path" of Scaliger's speaker's "daring feet" liberates him neither from his chains nor, a fortiori, from his body - the body being Marsilio Ficino's plausible interpretation of the chains worn by Plato's prisoners. ${ }^{73}$ Scaliger's speaker ascends to physicality, vulnerability, uncertainty, and poetry: poetry, on this account, results not from the contemplation of the invisible world, but from suffering and then doing in the sensible one.

Scaliger never suggested that the inner life of an Aristotelian lover or, indeed, of any Aristotelian — should be pleasant or comfortable. In a posthumously published poem in iambics, "The Soul Is Torn," he combines the registers of epistemology and erotic passion to comment directly on "The World Is at Rest." As we learn from that poem's complete title, its speaker is "Torn by Various Passions," and Scaliger's later iambic poem explains why: "Whoever does much is also necessarily suffering much. / Nor does passion stop, even if the actor stops acting." ${ }^{\text {"4 }}$ Again explicating the New Epigrams after the fact, Scaliger also indirectly shows us here how "The World Is at Rest" exceeds the dimensions of a footnote to his philosophy. "The World Is at Rest" not only demonstrates how a determined Aristotelian might gloss the standard Petrarchan scene of painful desire, it also proposes that the inseparability of action and passion is the real reason why Petrarchan desire is painful to begin with. The beloved's lack or absence, Scaliger suggests, can only cause pain to a speaker who beats himself, in unstopping passion, like Achilles and Hector. The fantasy of limitless personal agency, on the other hand, is what Aristotelian philosophy obliges a well-informed poet to lose, becoming, like the speaker of "He Is in Anguish," at once "with me" and "without me." If the $I$ that remains is importantly and persuasively complicated, he is also, by Petrarchan standards, undeniably diminished.

${ }^{72}$ Ficino, 1491a, sig. 221 ${ }^{\mathrm{r}}$ (515a-b).

${ }^{73}$ For Ficino, see the argument to book 7 of the Republic, in Plato, sig. $220^{\mathrm{r}}$.

${ }^{74}$ Scaliger, 1573, 127 (book 4): "Distractio animi. / Qui multa agit: hunc multa simul pati necesse est. / Nec passio cessat, licet actione cesset.” 


\section{After the NEW EPIGRAMS: DiAgnosing SCAliger}

For better or worse, the unlikely experiment of the New Epigrams was not one that Scaliger chose to repeat. We saw how in 1546, when he published his collected poems, Scaliger subdued his Aristotelianism to an erudite whisper in the Thaumantia. Meanwhile, his reprinting of the New Epigrams in the same volume - though it left the poems essentially unchanged pruned back their titles from terminological exuberance to near banality. Our poem "He Is in Anguish from Intractable Imagining" becomes simply "Contrary Representations." Likewise, a poem titled in 1546 "He Dreams of His Beloved in Turin," had originally been titled "Sleep Is Quietness of the Senses and the Body: No Wonder that Sleep Reveals Both the Beauty and the Savagery of the Beloved: For Savagery Is the Opposite of Tranquillity." 75 Nor apparently did the New Epigrams make a compelling impression on posterity. Scaliger's younger associate Antonio da Gouveia (ca. 1505-66?), famous for defending Aristotle against the attacks of Petrus Ramus in a 1543 treatise, did experiment with the tortured tone of the New Epigrams in his own Epigrammata of 1539 - but the far more famous George Buchanan (1506-82), who also moved in Scaliger's circle in southern France, seems to have resisted their charms entirely. ${ }^{76}$

If the New Epigrams proved to be a relatively ephemeral text, this may be in part because it arose from a transient moment in Scaliger's intellectual life. At this very early point in his publishing career, Scaliger apparently sought an eye-catching and novel way of combining humanist and scholastic modes of writing - of announcing his own multifarious credentials, perhaps as much for his own benefit as for that of his learned readers. In Scaliger's improbable eroticization of Aristotle, we might also detect an element of polemic. His first published work, in 1531, was the earliest in a series of tracts against Erasmus, whom Scaliger considered jejune as a theorist of Latin style, inept as a textual critic, and addicted to unedifying Greek writers like Lucian and Aristophanes. ${ }^{77}$ To choose Aristotle as the exemplary Greek, and to allude to Aristotle's own humanist omnicompetence by writing poetry under his auspices, was clearly to mark out a very different way of dealing with classical texts - a way that Scaliger may rightly have calculated would remain his alone.

\footnotetext{
${ }^{75}$ Scaliger, 1546, 66: "Contrariae repraesentationes"; 71: "In Taurinis somniat Amicam"; and 1533, sig. 20v: "Somnus quies est sensuum, \& corporis, non miratur somno redditam amicae uenustatem, sed saeuitiam: saeuitia enim tranquillitati contraria."

${ }^{76}$ See Gouveia, 1539 and 1543.

${ }^{77}$ See Scaliger, 1999; and on Erasmus's predilection for Lucian and Aristophanes, see Hippocrates, 1539 , sig. $\beta 2^{v}$.
} 
The problem was that such poetry had no obvious use beyond demonstrating Scaliger's cleverness, and little in the way of an obvious audience. The New Epigrams assumed that its readers both knew and cared about Aristotle's psychology and the debates around it in the 1520s and 1530 s - an ideal group that existed but was neither large nor remarkable for its social cachet. As Petrarchan poetry, meanwhile, the New Epigrams are relatively unsatisfactory, resolutely depressing in their tone and unlikely to give much help in seductions, imaginary or real. At some point before 1546, accordingly, Scaliger decided he was capable of writing Latin erotic verse that was not rebarbative - a discovery probably aided by his acquisition of a female patron, Constanza Rangone, to whom both the Thaumantia volume and the entire collected Poematia were dedicated. More generally, Scaliger seems to have developed an increasing taste for displaying himself in ways that elite audiences found noteworthy, if not fully comprehensible. In the Poetics, while describing the pyrrhic dance an ancient Spartan dance performed in full armor while the dancer sang poetry to the accompaniment of flutes - Scaliger remarks offhandedly, "I performed this often and at length before the Emperor Maximilian, at the command of his uncle Boniface, which did not fail to amaze all Germany." ${ }^{78}$ Although we have license to doubt whether this scene really took place, the reported spectacle fulfilled exactly the two wishes that Scaliger, as a poet, had found incompatible: while reenacting a little-known facet of antiquity, involving much advance research and great energy in the execution, the dancing Scaliger also enjoyed the rapt attention of an emperor and his court, often and at length.

Not only was the synthesis of the New Epigrams difficult and unfamiliar in its nature, Scaliger himself seems to have been wary of combining his philosophical and poetic discourses as fully as he potentially might have. For example, the New Epigrams consistently avoids the poetics of erotic symptomatology, the woeful catalogue of weak knees, thin blood, and bilious livers that fill the pages of other contemporary Petrarchans, and that one might have expected from a poet who was also a student of physiology and a practicing physician. Conversely, while in the New Epigrams Scaliger easily performs the personal, autobiographical style required by the genre,

${ }^{78}$ Scaliger, 1561, 28 (1.18): "Hanc nos \& saepe \& diu coram Diuo Maximiliano iussu Bonifacii patrui, non sine stupore totius Germaniae repraesentauimus.” Billanovich, 227, considers it unlikely that Scaliger spent time at Maximilian's court. On the pyrrhic dance, see McGowan.

${ }^{79}$ On others who sang Latin poetry in public, including Poliziano, Egidio da Viterbo, and numerous ancients, see Brandolini, xxiv-xxxi, 82-85, 108-15. 
his commentary on Hippocrates eschews autobiography and experience completely, never recounting Scaliger's own medical dreams or those of his patients. In this strict preference for the general, Scaliger's commentary resembles Nifo's treatise on the art of interpreting dreams, along with many other contemporary Aristotelian texts. But by the same measure, Scaliger differs radically from many medical writers, such as the effusively autobiographical Galen, and Scaliger's younger contemporary Girolamo Cardano: perhaps as a rejoinder to Scaliger and others, Cardano discusses real cases, including his own, at every opportunity, both in his commentaries on Hippocrates and, above all, in his 1562 treatise on dream interpretation. ${ }^{80}$

Eventually, of course, Scaliger gave up altogether on the project of uniting humanism and scholasticism through poetry, whether jarringly or subtly. The vastness of his Poetics suggests that it was a much easier task for Scaliger to proclaim Aristotle's universality by applying the philosopher's expository methods to literature than by infarcing Aristotelian doctrines into new literary forms. Another crucial advantage resulted from this approach: even readers blissfully unaware of Scaliger's methodological preoccupations could readily learn from the Poetics without preliminaries. The only qualification necessary, broadly speaking, was a willingness to digest long, seemingly disconnected, and often repetitive paragraphs of Latin - and to make frequent use of the table of contents, in order to find, for example, the two chapters on the epigram that Scaliger saw fit to nest away in two different books. That readers were willing to do this for two centuries after Scaliger's death reminds us that the strangeness of the New Epigrams was both relative and profound.

If the story of the New Epigrams remains largely a story about encounters with and between books, it nonetheless shows us several things about life with Aristotle's books in the sixteenth century - a topic about which we have learned much in the last decade or two. ${ }^{81}$ In the first place, for Scaliger's purposes in 1533, Aristotle occupied a complicated chronological place, at once old and new. While it was the older discourse of Aristotelian psychology that allowed Scaliger to revise the newly fashionable discourse of Petrarchan poetry, the very idea of composing Aristotelian poetry also proceeded from Quattrocento arguments about the universal humanistic competence of the philosopher, arguments that in the 1530s were already on their way to obsolescence. In turn, Scaliger's picture of the historical Aristotle as an exemplary figure - a tool for guidance and self-figuration — invites us to think about Scaliger's own posture as an Aristotelian intellectual,

\footnotetext{
${ }^{80}$ Siraisi, 1997, 118-91; Grafton, 1999, especially 156-77.

${ }^{81}$ See Mulsow; James; Maclean; Kusukawa; Pade; Blackwell and Kusukawa.
} 
about what it meant and, perhaps, how it felt to perform within the bounds of books. Like the merciless beloved in Scaliger's poem "The World Is at Rest," Aristotle was overwhelmingly present in the intellectual world Scaliger constructed for himself, striking his commentators to make them speak. On the other hand, that poem's insistence on the interdependence of action and passion, not to mention the example of Scaliger's commentary on Hippocrates, reminds us that the erotics of tradition could also yield a discourse of deep engagement and close questioning. Indeed, it seems likely that for Scaliger any other sort of discourse was inconceivable: escaping the beloved's authority, never a realistic option in Scaliger's philosophical writings, was imagined in his poem's ending as a plangent, perhaps suicidal, act not easily distinguishable from madness. Perpetually a commentator - struck and marked by the authoritative texts of his culture Scaliger was also, like the Petrarchan lover, perpetually discontented and fractious, even and especially at the moments when he most loudly declared his bondage and his love.

California Institute of TeChnology 


\section{Bibliography}

Albertus Magnus. Parva naturalia. Venice, 1517.

Aristotle. Historia de animalibus. Trans. and commentary Julius Caesar Scaliger. Toulouse, 1619.

- - On the Soul; Parva naturalia; On Breath. Trans. W. S. Hett. Cambridge, MA, 1935.

Athenaeus. The Deipnosophists. Ed. and trans. Charles Burton Gulick. 7 vols. Cambridge, MA, 1927-41.

Averroes. Compendia librorum Aristotelis qui Parva naturalia vocantur. Ed. A. L. Shields. Cambridge, MA, 1949.

Avicenna. A Treatise on the Canon of Medicine of Avicenna Incorporating a Translation of the First Book. Ed. O. Cameron Gruner. London, 1930.

Barbaro, Ermolao. "Praefatio Hermolai Barbari, cum libros Aristotelis domi coepit praelegere." In Angelo Poliziano, Opera omnia, sigg. $s 8^{\mathrm{r}}-\mathrm{t} 1^{\mathrm{r}}$. Venice, 1498.

- Epistolae, orationes et carmina. Ed. Vittore Branca. 2 vols. Florence, 1943.

Billanovich, Myriam. "Benedetto Bordon e Giulio Cesare Scaligero.” Italia medioevale e umanistica 11 (1968): 187 256.

Blackwell, Constance, and Sachiko Kusukawa, eds. Philosophy in the Sixteenth and Seventeenth Centuries: Conversations with Aristotle. Aldershot, 1999.

Bottiglioni, Gino. La lirica latina in Firenze nella 2.a metà del secolo $X V$. Pisa, 1913.

Bradner, Leicester. "The Neo-Latin Epigram in Italy in the Fifteenth Century." Medievalia et Humanistica 8 (1954): 62-70.

Brandolini, Raffaele. On Music and Poetry (De musica et poetica, 1513). Trans. Ann Moyer. Tempe, 2001.
Bray, René. La formation de la doctrine classique en France. Paris, 1927.

Buck, August. Italienische Dichtungslehren vom Mittelalter bis zum Ausgang der Renaissance. Tübingen, 1952.

Catanzaro, Giuseppe, and Francesco Santucci, eds. Poesia umanistica latina in distici elegiaci. Assisi, 1999.

Celenza, Christopher S. "Petrarch, Latin, and Italian Renaissance Latinity." Journal of Medieval and Early Modern Studies 35 (2005): 509-36.

Diogenes Laertius. De uita \& moribus philosophorum. Venice, 1490.

. De uitis, decretis, \& responsibus celebrium philosophorum. Basel, 1533.

Erasmus, Desiderius. Opera omnia. Ed. Conseil international pour l'édition des oeuvres complètes d'Erasme. 7 vols. Amsterdam, 1969-.

Ficino, Marsilio. "Argumentum in septimum librum de iusto." In Plato, Opera omnia, trans. Marsilio Ficino, fol. $219^{\mathrm{v}}-221^{\mathrm{r}}$. Venice, 1491a.

. "Platonis vita." In Plato, Opera omnia. Trans. Marsilio Ficino, sigg. $\mathrm{a} 2^{\mathrm{r}}-\mathrm{a} 4^{\mathrm{v}}$. Venice, $1491 \mathrm{~b}$.

Florilegium diversorum epigrammatum in septem libros. Paris, 1531.

Forster, Leonard. "On Petrarchism in Latin and the Role of Anthologies." In Acta Conventus Neo-Latini Lovaniensis, ed. Josef Ijsewijn and Eckhard Kessler, 235-44. Leuven, 1973.

Garanderie, Marie-Madeleine. "Jules-César Scaliger commentateur d'Hippocrate." In Acta Scaligeriana, ed. Jean Cubelier de Beynac and Michel Magnien, 24555. Agen, 1986.

Genette, Gérard. Palimpsests: Literature in the Second Degree. Trans. Channa Newman and Claude Doubinsky. Lincoln, 1997.

Gouveia, Antonio da. Epigrammatwn libri duo. Paris, 1539. 
- Pro Aristotele responsio, adversus $P$. Rami calumnias. Paris, 1543.

Grafton, Anthony. "Renaissance Readers of Homer's Ancient Readers." In Homer's Ancient Readers: The Hermeneutics of Greek Epic's Earliest Exegetes, ed. Robert Lamberton and John J. Keaney, 149-72. Princeton, 1992.

- Cardano's Cosmos: The Worlds and Works of a Renaissance Astrologer. Cambridge, MA, 1999.

Guarino da Verona. "Aristotelis Vita." In Aristotelis ... opera omnia. Basel, 1563.

Hippocrates. Hippocratis Coi medicorum omnium longe principis, octoginta volumina. Trans. Marco Fabio Calvo. Rome, 1525.

- Hippocratis opera omnia. Venice, 1526.

- Liber de somniis cum Iulii Caesaris Scaligeri commentariis. Lyon, 1539.

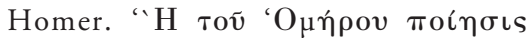
$\dddot{\alpha} \pi \alpha \sigma \alpha$. Ed. Demetrius Chalcondylas. Florence, 1489.

Hutton, James. The Greek Anthology in Italy to the Year 1800. Ithaca, 1935.

James, Susan. Passion and Action: The Emotions in Seventeenth-Century Philosophy. Oxford, 1997.

Jensen, Kristian. Rhetorical Philosophy and Philosophical Grammar: Julius Caesar Scaliger's Theory of Language. Munich, 1990.

Jouanna, Jacques. "L'Interprétation des rêves et la théorie micro-macrocosmique dans le traité hippocratique $D u$ régime: sémiotique et mimesis." In Text and Tradition: Studies in Ancient Medicine and Its Transmission Presented to Jutta Kollesch, ed. KlausDietrich Fischer, Diethard Nickel, and Paul Potter, 161-74. Leiden, 1998.
Keller, Luzius. “'Solo e pensoso,' 'Seul et pensif,' 'Solitaire et pensif,' mélancolie pétrarquienne et mélancolie pétrarquiste." In Übersetzung und Nachahmung im europäischen Petrarkismus. Studien und Texte, ed. Luzius Keller, 89-103, 288-302. Stuttgart, 1974.

Kraye, Jill. "Ficino in the Firing Line: A Renaissance Neoplatonist and His Critics." In Marsilio Ficino: His Theology, His Philosophy, His Legacy, ed. Michael J. B. Allen and Valery Rees, 377-97. Leiden, 2002.

Kusukawa, Sachiko. The Transformation of Natural Philosophy: The Case of Philip Melanchthon. Cambridge, 1995.

Lamberton, Robert, and John J. Keaney, eds. Homer's Ancient Readers: The Hermeneutics of Greek Epic's Earliest Exegetes. Princeton, 1992.

Ludwig, Walther. "Plato's Love Epigrams." Greek, Roman, and Byzantine Studies 4 (1963): 59-82.

- "Petrus Lotichius Secundus and the Roman Elegists: Prolegomena to a Study of Neo-Latin Elegy." In Classical Influences on European Culture A. D. 1500-1700, ed. R. R. Bolgar, 171-90. Cambridge, 1976.

Lüthy, Christoph. "An Aristotelian Watchdog as Avant-Garde Physicist: Julius Caesar Scaliger." Monist 84 (2001): 542-561.

Maclean, Ian. Logic, Signs and Nature in the Renaissance: The Case of Learned Medicine. Cambridge, 2002.

Mahoney, Edward P. "Plato and Aristotle in the Thought of Agostino Nifo (ca. 1470-1538)." In Platonismo e aristotelismo nel mezzogiorno d'Italia (secc. $X I V-X V I)$, ed. Giuseppe Roccaro, 81-101. Palermo, 1989.

Maïer, Ida. Ange Politien: La formation d'un poète humaniste (1469-1480). Geneva, 1966. 
McGowan, Margaret M. "A Renaissance War Dance: The Pyrrhic.” Dance Research 3 (1984): 29-38.

McLaughlin, Martin L. Literary Imitation in the Italian Renaissance: The Theory and Practice of Literary Imitation in Italy from Dante to Bembo. Oxford, 1995.

Megna, Paola. Lo 'Ione' platonico nella Firenza medicea. Messina, 1999.

Mulsow, Martin. Frühneuzeitliche Selbsterhaltung. Telesio und die Naturphilosophie der Renaissance. Tübingen, 1998.

Nichols, Fred. "The Literary Relationships of the Poemata of Julius Caesar Scaliger." PhD diss., Columbia University, 1967.

Nifo, Agostino. "De artificiosa somniorum interpretatione." In Parva naturalia, by Aristotle, sigg. $115^{\mathrm{r}}-119^{\mathrm{v}}$. Venice, 1523.

- De pulchro liber, printed with De amore. Rome, 1531.

- De pulchro et amore/Du beau et de l'amour, I: De pulchro liber/Le livre $d u$ beau. Ed. and trans. Laurence Boulègue. Paris, 2003.

Nussbaum, Martha, ed. Love's Knowledge: Essays on Philosophy and Literature. Oxford, 1990.

- The Therapy of Desire: Theory and Practice in Hellenistic Ethics. Princeton, 1994.

Nutton, Vivian. John Caius and the Manuscripts of Galen. Cambridge, 1987.

Pade, Marianne, ed. Renaissance Readings of the Corpus Aristotelicum. Copenhagen, 2001.

Padelford, Francis Morgan. Select Translations from Scaliger's 'Poetics'. 1905. Reprint, New York, 1995.

Perfetti, Stefano. "Giulio Cesare Scaliger commentatore e filosofo naturale tra Padova e Francia." In La presenza dell'aristotelismo padovano nella filosofia della prima modernità, ed. Gregorio Piaia, 3-31. Rome and Padua, 2002.

Petrarca, Francesco. Rime e trionfi. Ed. Ferdinando Neri. $2^{\text {nd }}$ rev. ed. Turin, 1960.

Plato. Opera. Trans. Marsilio Ficino. Venice, 1491.

Poliziano, Angelo. Opera omnia. Venice, 1498.

Rose, Valentin. Aristoteles pseudepigraphus. Leipzig, 1863. Reprint, Hildesheim, 1971.

Roselli, Amneris. "I Sogni di Ippocrate nell'interpretazione di Giulio Cesare Scaligero." In Il sogno raccontato: atti del convegno internazionale di Rende, 12-14 novembre 1992, ed. Nicola Merola and Caterina Verbaro, 13750. Vibo Valentia, 1995.

Scaliger, Julius Caesar. Novorum epigrammatum liber unicus. Paris, 1533.

- De causis linguae latinae. Lyon, 1540.

- Poematia. Lyon, 1546.

. Exotericarum exercitationum liber quintus decimus. Paris, 1557.

- Poetices libri septem. Lyon, 1561.

- Epidorpides. Geneva, 1573.

- Poemata. Heidelberg, 1574.

. Poetices libri septem. Sieben Bücher über die Dichtkunst. Ed. Luc Deitz and Gregor Vogt-Spira. 5 vols. Stuttgart, 1994-.

- Oratio pro M. Tullio Cicerone contra des. Erasmum, 1531. Adversus des. Erasmi Roterod. Dialogum Ciceronianumoration secunda, 1537. Ed. Michel Magnien. Geneva, 1999.

Siraisi, Nancy. Avicenna in Renaissance Italy: The 'Canon' and Medical Teaching in Italian Universities after 1500. Princeton, 1987.

- The Clock and the Mirror: Girolamo Cardano and Renaissance Medicine. Princeton, 1997. 
Smith, Wesley D. The Hippocratic Tradition. Ithaca, 1979.

van der Eijk, Philip J. "Aristotle on 'Distinguished Physicians' and on the Medical Significance of Dreams." In Ancient Medicine in Its Socio-Cultural Context, ed. P. J. van der Eijk et al., 2:447-59. Amsterdam, 1995.

-. "Aristotle on Cognition in Sleep."
In Sleep, ed. T. Wiedemann and K. Dowden, 25-40. Bari, 2003.

Wear, Andrew, R. K. French, and I. M. Lonie, eds. The Medical Renaissance of the Sixteenth Century. Cambridge, 1985.

Weinberg, Bernard. A History of Literary Criticism in the Italian Renaissance. 2 vols. Chicago, 1961. 